\title{
The Relationship between Sketch and Personality: The Narcissistic Personality Inventory Research
}

\author{
Ching-Yi Wang \\ Department of Creative Product Design, Asia University, Taichung, Taiwan \\ Email: catincar@gmail.com
}

Received 26 February 2015; accepted 15 April 2015; published 23 April 2015

Copyright (C) 2015 by author and Scientific Research Publishing Inc.

This work is licensed under the Creative Commons Attribution International License (CC BY).

http://creativecommons.org/licenses/by/4.0/

(c) () Open Access

\begin{abstract}
This study investigated 73 designed beginners who drew the Venus plaster and completed the 7dimensional Narcissistic Personality Inventory (NPI) test. Next, 5-point scales were used to compare the degrees of the facial similarity between the paintings and photos of the beginners who created the paintings. The results indicated that over half of the paintings were similar to the photos of the painters, and the similarity was significantly correlated with narcissism. For example, the painters with self-sufficient personalities were more likely to exhibit assertiveness, independence, self-confidence, and need for achievement; thus, they were automatically drawn to their own sense of personal feelings as projected onto the drawings, which naturally tended to look like themselves. These results might help the educators in the design field identify the likely NPI-associated psychological and behavioral outcomes of design beginners by observing the contexts of their paintings.
\end{abstract}

\section{Keywords}

Narcissistic Personality Inventory, Psychology, Sketch, Questionnaire

\section{Introduction}

Are you aware of why novice artists create pieces that reflect their individual personalities? Before this experiment, I found that design beginner's paintings of the Venus plaster look somewhat like the beginners themselves. Does this phenomenon imply that the content of a painting is really hiding unknown aspects of the designer's personality? Many researchers have begun to show a growing interest in the psychological aspects of human drawings since the end of the 19th century. The Draw-A-Person (DAP) test (Machover, 1949) is one of the most 
frequently used techniques by clinical psychologists (Anastasi \& Urbina, 1994; Armstrong \& Hauch, 1961; Arteche et al., 2010; Hammer, 1997; Haworth \& Normington, 1961; Skybo et al., 2007; McHugh, 1966; Swensen, 1968; Willcock et al., 2011). Furthermore, there have been numerous assertions that figure drawings, as projections of inner feelings, thoughts, conflicts, compensations, and perceptions, significantly reflect personality features (Daoud \& Breik, 2009). The underlying assumption is that a person projects important aspects of his or her "self-image" when asked to draw a figure (Aronoff \& McCormick, 1990; Goodenough \& Harris, 1950; Isaksson et al., 2009; Sidun \& Rosenthal, 1987; Stucke \& Sporer, 2002). This study assumed that the phenomenon of reflecting self-image onto Venus drawings might be particularly associated with narcissism.

Narcissism has been well-described in the literature (Ackerman et al., 2011; Corry et al., 2008; Dimaggio et al., 2008; Emmons, 1984, 1987; Holtzman \& Strube, 2010; Kubarych et al., 2004; Pincus \& Lukowitsky, 2010; Raskin \& Hall, 1979, 1981; Raskin \& Terry, 1988; Reidy et al., 2008). Narcissism is typically operationalized using the relatively recently created 40-item forced choice narcissistic personality inventory (NPI, Raskin \& Terry, 1988). A sample item of this inventory is "I really like to be the center of attention" vs. "It makes me uncomfortable to be the center of attention". Raskin and Terry (1988) decomposed the 40-item NPI into the following seven component scales: authority, exhibitionism, superiority, entitlement, exploitativeness, self-sufficiency, and vanity. Some diseases are associated with narcissism. Guez et al. (2010) asked patients with eating disorders to draw self-image and found that the bulimic patients' portrayals of body size were significantly larger than those of the anorectic patients. Becker et al. (2006) indicated that bulimic patients exhibit a greater number of narcissist characteristics than do anorectic patients because bulimic patients are often concerned about being recognized and acknowledged as an attractive person. Thus, narcissism provides a new perspective to better understand these patients' psychologies offer suitable treatments.

Narcissism is characterized in part by an acute concern for one's appearance. In an earlier study, Machover (1949) distinguished two types of narcissism, "clothing-narcissism" and "body narcissism", based on drawings of human figures. The former is characterized by the desire of extraverts to be appreciated, the desire to make a good impression and the narcissistic need for social regard, and the latter is characterized by introversion and a narcissistic fixation on the body (Vass, 2012: p. 332). To date, many studies have confirmed that the narcissists with self-esteem create a "mirror" image (Kohut, 1971, 1977; Brudniy \& Demilhanova, 2012) via self-enhancement and self-serving behaviors to achieve an external agreement with the representation of normal "self-image" (Campbell et al., 2000; Kurt \& Paulhus, 2008). Vazire et al. (2008) reported that, regarding physical appearance, narcissists are more likely to wear expensive, flashy clothing and to exhibit an organized and neat appearance that required a large amount of preparation. Furthermore, female narcissists are more likely to wear makeup, show cleavage and capture the unique constellation of personality traits that are typical of narcissists (e.g., high extraversion and low agreeableness). These findings imply that physical appearance reflects and serve the narcissist's personality, preoccupation with good looks, and desire to be the center of attention.

Additionally, people are more likely to be attracted to their own faces (Little et al., 2003, 2011; Bereczkei et al., 2002; Penton-Voak et al., 1999; Zajonc et al., 1987). Penton-Voak et al. (1999) asked participants to judge the attractiveness of facial photos. Using computer graphic techniques, opposite sex facial stimuli were generated from photographs of the participant. The faces that were rated "most attractive" were the photographs of each participant, which suggests that people are attracted to people with appearances similar to their own. Rushton and Bons (2005) demonstrated that genetic and environmental factors contribute to people's preferences for spouses and friends that are similar to themselves. These findings imply that the people choose mates with similar genetic compositions. Facial attractiveness might be the underlying cause of narcissists' self-focus and public display (Holtzman \& Strube, 2010; Moskowitz et al., 2009), which suggests that narcissism and attractiveness are positively correlated. We hypothesized that this phenomenon, which is termed "couple-face", might be a manifestation of narcissism and that mate choices would thus be affected to some degree by the narcissistic personality.

The aim of this study was to examine why self-images were reflected in the Venus paintings. Is this reflection really associated with narcissism, and which underlying domains were the most likely to be affected? Here, we performed an experiment similar to Machover's DAP test (but without self-figure drawing) in which design beginners were asked to draw the Venus plaster. The 40-item NPI of (Raskin \& Novacek, 1989) and its seven dimensions were used to assess the correlation between the extent to which the drawings reflected the artists' self-images and narcissism. We assumed that the narcissism involved this self-centeredness might explain the phenomenon of the reflection of self-images onto the Venus drawings. 


\section{Material and Methods}

\subsection{Participants}

A total of 73 participants (27 male, 46 female; mean age $=21$ years; $S D=1.24$; range $=20-27$ years) from a creative product design program of Asia University were invited to participate in the experiment. All of the participants were beginning painters, native Chinese speakers, and had normal or corrected-to-normal vision.

\subsection{Venus Paintings}

The participants were divided into 4 groups. Each group sat facing a plaster in a professional graphics classroom. The participants were asked use charcoal to draw the head of the plaster Venus (Figure 1) on a white paper. The plaster is composed of multiple geometric surfaces to be used to train design beginners to observe and paint the changes of the light and the shadow on each surface. Each painting was approximately $54.5 \mathrm{~cm}$ high and 39.3 $\mathrm{cm}$ wide. All paintings required approximately 6 hours to complete. A total of 73 charcoal Venus paintings were selected by 5 experts with product design experiences over 15 years ( 3 male, 2 female; mean age $=43$ years; $\mathrm{SD}=3.85$; range $=38-48$ years). The selected paintings were clear and represented vertical and horizontal visual angles that subtended approximately 0 to 45 degrees to ensure a clear view of the face.

\subsection{Narcissistic Personality Inventory (NPI) Personality Test}

After painting, the participants were asked to complete the NPI test by selecting the statements that best described themselves (see Table 1). The numbers of items for each of the seven dimensions were 8, 7, 5, 6, 5, 6, and 3. The analyses of the seven dimensions of the NPI were based on the sums of the items in each dimension.

\subsection{Facial Similarity Rating Questionnaire}

Finally, the participants were asked to complete an online version of the questionnaire. In order to measure the participants' reactions to objects or images, the most popular method in the design study is to apply adjectival descriptions of the semantic differences (SD) and multidimensional scale (MDS). For example, such methods were used in numerous Kansei engineering research projects in Japan (Nagamachi, 1995) and in multidimensional space research (Green \& Smith, 1989; Hsiao \& Chen, 1997). These studies use questionnaires with a Likert scale, mostly based on the semantics analysis developed by Osgood in 1957, to acquire the participant's subjective responses to stimuli. Different bipolar adjectives (e.g., simple-complicated, plain-luxurious) are tested according to the stimuli and context, in the semantic differential measurement. Therefore, the participants assessed the degrees of facial similarity between photos of the artists and their Venus paintings (see Table 2) on a 5-point Likert-type scale that ranged from 1 (not at all like him/her) to 5 (exactly like him/her). Each author' sphoto was grey-scale on a white background and displayed at vertical and horizontal visual angles that a subtended approximately 0 degrees. All of participants have given permission for their photographs to be published.

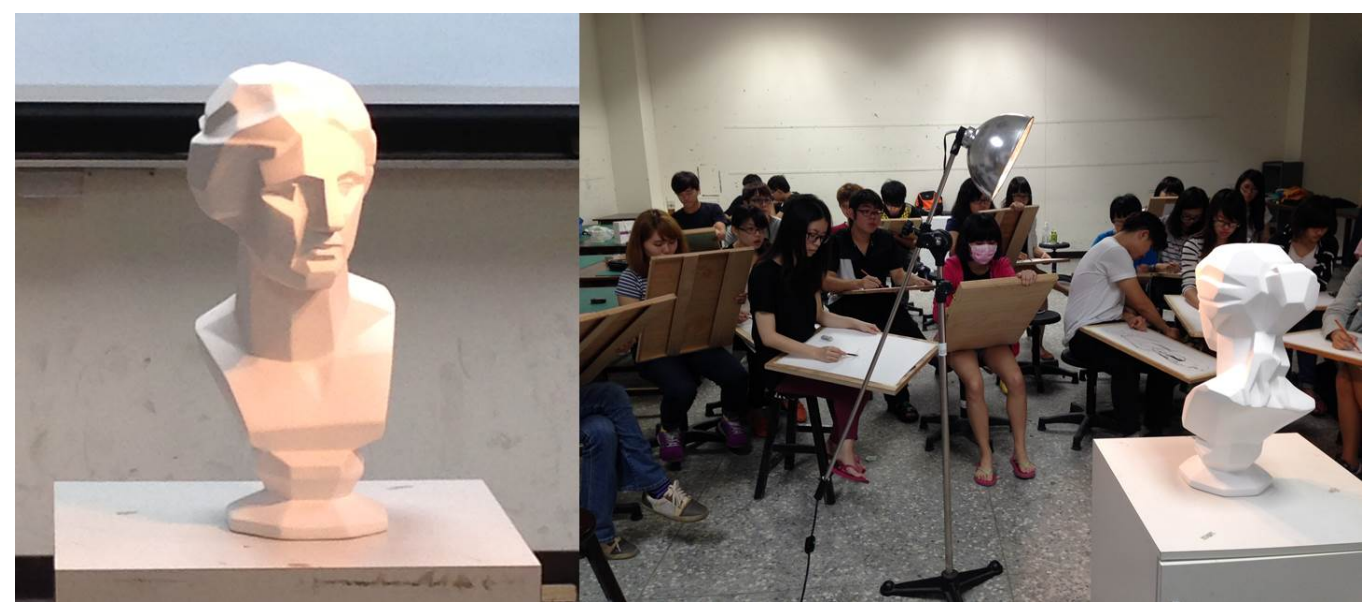

Figure 1. Venus plaster (left) and the participants sitting around it (right). 
Table 1. 40-item pair measure of Narcissism.

\begin{tabular}{|c|c|c|c|}
\hline No. & Item & A & B \\
\hline 1 & $\begin{array}{l}\text { A. I have a natural talent for influencing people. } \\
\text { B. I am not good at influencing people. }\end{array}$ & 1 & 0 \\
\hline 2 & $\begin{array}{l}\text { A. Modesty doesn't become me. } \\
\text { B. I am essentially a modest person. }\end{array}$ & 1 & 0 \\
\hline 3 & $\begin{array}{l}\text { A. I would do almost anything on a dare. } \\
\text { B. I tend to be a fairly cautious person. }\end{array}$ & 1 & 0 \\
\hline 4 & $\begin{array}{l}\text { A. When people compliment me I sometimes get. } \\
\text { B. I know that I am good because everybody keeps telling me so. }\end{array}$ & 0 & 1 \\
\hline 5 & $\begin{array}{l}\text { A. The thought of ruling the world frightens the hell out of me. } \\
\text { B. If I ruled the world it would be a better place. }\end{array}$ & 0 & 1 \\
\hline 6 & $\begin{array}{l}\text { A. I can usually talk my way out of anything. } \\
\text { B. I try to accept the consequences of my behavior. }\end{array}$ & 1 & 0 \\
\hline 7 & $\begin{array}{l}\text { A. I prefer to blend in with the crowd. } \\
\text { B. I like to be the center of attention. }\end{array}$ & 0 & 1 \\
\hline 8 & $\begin{array}{l}\text { A. I will be a success. } \\
\text { B. I am not too concerned about success. }\end{array}$ & 1 & 0 \\
\hline 9 & $\begin{array}{l}\text { A. I will be a success. } \\
\text { B. I am not too concerned about success. }\end{array}$ & 0 & 1 \\
\hline 10 & $\begin{array}{l}\text { A. I am not sure if I would make a good leader. } \\
\text { B. I see myself as a good leader. }\end{array}$ & 0 & 1 \\
\hline 11 & $\begin{array}{l}\text { A. I am assertive. } \\
\text { B. I wish I were more assertive. }\end{array}$ & 1 & 0 \\
\hline 12 & $\begin{array}{l}\text { A. I like to have authority over other people. } \\
\text { B. I don't mind following orders. }\end{array}$ & 1 & 0 \\
\hline 13 & $\begin{array}{l}\text { A. I find it easy to manipulate people. } \\
\text { B. I don't like it when I find myself manipulating people. }\end{array}$ & 1 & 0 \\
\hline 14 & $\begin{array}{l}\text { A. I insist upon getting the respect that is due me. } \\
\text { B. I usually get the respect that I deserve. }\end{array}$ & 1 & 0 \\
\hline 15 & $\begin{array}{l}\text { A. I don’t particularly like to show off my body. } \\
\text { B. I like to show off my body. }\end{array}$ & 0 & 1 \\
\hline 16 & $\begin{array}{l}\text { A. I can read people like a book. } \\
\text { B. People are sometimes hard to understand. }\end{array}$ & 1 & 0 \\
\hline 17 & $\begin{array}{l}\text { A. If I feel competent I am willing to take responsibility for making decisions. } \\
\text { B. I like to take responsibility for making decisions. }\end{array}$ & 0 & 1 \\
\hline 18 & $\begin{array}{l}\text { A. I just want to be reasonably happy. } \\
\text { B. I want to amount to something in the eyes of the world. }\end{array}$ & 0 & 1 \\
\hline 19 & $\begin{array}{l}\text { A. My body is nothing special. } \\
\text { B. I like to look at my body. }\end{array}$ & 0 & 1 \\
\hline 20 & $\begin{array}{l}\text { A. I try not to be a show off. } \\
\text { B. I will usually show off if I get the chance. }\end{array}$ & 0 & 1 \\
\hline 21 & $\begin{array}{l}\text { A. I always know what I am doing. } \\
\text { B. Sometimes I am not sure of what I am doing. }\end{array}$ & 1 & 0 \\
\hline 22 & $\begin{array}{l}\text { A. I sometimes depend on people to get things done. } \\
\text { B. I rarely depend on anyone else to get things done. }\end{array}$ & 0 & 1 \\
\hline 23 & $\begin{array}{l}\text { A. Sometimes I tell good stories. } \\
\text { B. Everybody likes to hear my stories. }\end{array}$ & 0 & 1 \\
\hline 24 & $\begin{array}{l}\text { A. I expect a great deal from other people. } \\
\text { B. I like to do things for other people. }\end{array}$ & 1 & 0 \\
\hline 25 & $\begin{array}{l}\text { A. I will never be satisfied until I get all that I deserve. } \\
\text { B. I take my satisfactions as they come. }\end{array}$ & 1 & 0 \\
\hline 26 & $\begin{array}{l}\text { A. Compliments embarrass me. } \\
\text { B. I like to be complimented. }\end{array}$ & 0 & 1 \\
\hline
\end{tabular}




\section{Continued}

\begin{tabular}{|c|c|c|c|}
\hline 27 & $\begin{array}{l}\text { A. I have a strong will to power. } \\
\text { B. Power for its own sake doesn't interest me. }\end{array}$ & 1 & 0 \\
\hline 28 & $\begin{array}{l}\text { A. I don't care about new fads and fashions. } \\
\text { B. I like to start new fads and fashions. }\end{array}$ & 0 & 1 \\
\hline 29 & $\begin{array}{l}\text { A. I like to look at myself in the mirror. } \\
\text { B. I am not particularly interested in looking at myself in the mirror. }\end{array}$ & 1 & 0 \\
\hline 30 & $\begin{array}{l}\text { A. I really like to be the center of attention. } \\
\text { B. It makes me uncomfortable to be the center of attention. }\end{array}$ & 1 & 0 \\
\hline 31 & $\begin{array}{l}\text { A. I can live my life in any way I want to. } \\
\text { B. People can't always live their lives in terms of what they want. }\end{array}$ & 1 & 0 \\
\hline 32 & $\begin{array}{l}\text { A. Being an authority doesn't mean that much to me. } \\
\text { B. People always seem to recognize my authority. }\end{array}$ & 0 & 1 \\
\hline 33 & $\begin{array}{l}\text { A. I would prefer to be a leader. } \\
\text { B. It makes little difference to me whether I am a leader or not. }\end{array}$ & 1 & 0 \\
\hline 34 & $\begin{array}{l}\text { A. I am going to be a great person. } \\
\text { B. I hope I am going to be successful. }\end{array}$ & 1 & 0 \\
\hline 35 & $\begin{array}{l}\text { A. People sometimes believe what I tell them. } \\
\text { B. I can make anybody believe anything I want them to. }\end{array}$ & 0 & 1 \\
\hline 36 & $\begin{array}{l}\text { A. I am a born leader. } \\
\text { B. Leadership is a quality that takes a long time to develop. }\end{array}$ & 1 & 0 \\
\hline 37 & $\begin{array}{l}\text { A. I wish somebody would someday write my biography. } \\
\text { B. I don't like people to pry into my life for any reason. }\end{array}$ & 1 & 0 \\
\hline 38 & $\begin{array}{l}\text { A. I get upset when people don't notice how I look when I go out in public. } \\
\text { B. I don't mind blending into the crowd when I go out in public. }\end{array}$ & 1 & 0 \\
\hline 39 & $\begin{array}{l}\text { A. I am more capable than other people. } \\
\text { B. There is a lot that I can learn from other people. }\end{array}$ & 1 & 0 \\
\hline 40 & $\begin{array}{l}\text { A. I am much like everybody else. } \\
\text { B. I am an extraordinary person. }\end{array}$ & 0 & 1 \\
\hline
\end{tabular}

Note: The number " 1 " represents the Narcissistic response, and the " 0 " means the Non-narcissistic response. The 7-dimensions of NPI involved items, including: (1) Authority (No. 1, 8, 10, 11, 12, 32, 33, 36); (2) Exhibitionism (No. 2, 3, 7, 20, 28, 30, 38); (3) Superiority (No. 4, 9, 26, 37, 40); (4) Entitlement (No. 5, 14, 18, 24, 25, 27); (5) Exploitativeness (No. 6, 13, 16, 23, 35); (6) Self-sufficiency (No. 17, 21, 22, 31, 34, 39); (7) Vanity (No. 15, 19, 29).

Table 2. Example of similarity rating between the author' photo and the Venus painting on the 5-point scales (5 = Exactly Like; 1 = Totally Unlike): (a) the painting was displayed at approximately 0 degree; (b) the painting was displayed at approximately 45 degrees.
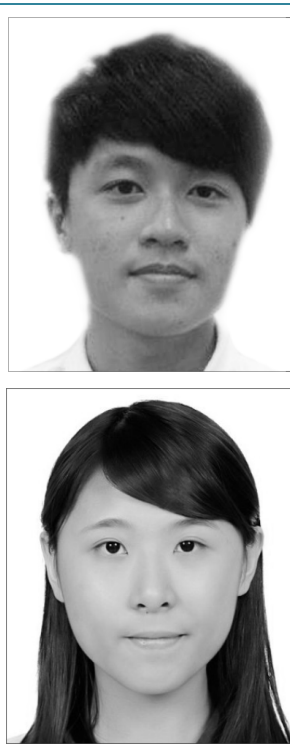

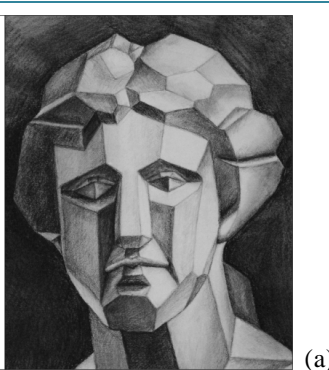

(a)

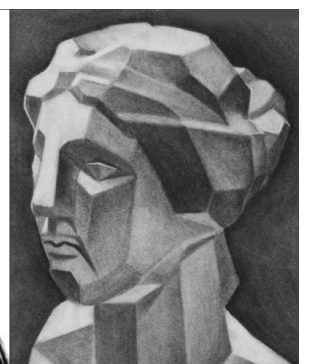

$1 \square 0 \%$ not at all like him

$2 \square 25 \%$ a bit like him

$3 \square 50 \%$ half and half like him

$4 \square$ 75\% very much like him

$5 \square$ 100\% exactly like him

$1 \square 0 \%$ not at all like her

$2 \square$ 25\% a bit like her

$3 \square 50 \%$ half and half like her

$4 \square$ 75\% very much like her

$5 \square$ 100\% exactly like her 


\section{Results}

Pearson's correlation tests were used to analyze association for the gender, the Narcissism, and the rating results.

\subsection{Facial Similarity Ratings}

Table 3 illustrates the rates of the facial similarities between the photos of the painters and their Venus paintings. The percentages of responses of $1,2,3,4$, and 5 rating were $21 \%, 28 \%, 28 \%, 17 \%$, and $6 \%$, respectively. The percentage of ratings that were greater than 3 was 51\%, which suggests that over half of the paintings were to the photos of the painters.

\subsection{Narcissism}

Table 4 illustrates the percentages of respondents to the scale that exhibited the authority, exhibitionism, superiority, entitlement, exploitativeness, self-sufficiency, and vanity dimensions. Based on the percentages, the dimensions observed were, in order of decreasing frequency authority, entitlement, exhibitionism, self-sufficiency, superiority, exploitativeness, and vanity. The scores in the authority dimension were greater than the scores in each of the other dimensions, and the lowest scores were observed in the vanity dimension.

\subsection{Correlations among Gender, Narcissism, and the Paintings}

Table 5 shows the correlations among the gender, the NPI dimensions, and the similarity ratings of the paintings. Analyses of the correlations between gender and each of the dimensions revealed significant negative associations with authority, exhibitionism, and vanity $(\mathrm{r}=-0.21, p<0.05 ; \mathrm{r}=-0.21, p<0.05$; $\mathrm{r}=-0.22, p<0.05$, respectively); these results suggest that the males and females exhibited different personalities in terms of these three dimensions. However, only the self-sufficiency dimension was significantly correlated with the similarity ratings ( $r=0.20, p<0.05$ ); this association indicates that the painters who exhibited this dimension might exhibit different psychological personalities.

Table 3. Distribution of the facial similarity ratings of the Venus paintings and the painters' photos on the 5-point scale ( $\mathrm{n}=$ 107).

\begin{tabular}{ccc}
\hline Rating Scales & Frequency & Percentage \\
\hline $0 \%$ Totally Unlike & 1651 & $21 \%$ \\
25\% A Bit Unlike & 2241 & $28 \%$ \\
$50 \%$ Half and Half Like & 2186 & $28 \%$ \\
$75 \%$ Very Much Like & 1323 & $17 \%$ \\
$100 \%$ Exactly Like & 473 & $6 \%$ \\
\hline
\end{tabular}

Table 4. Data regarding the seven dimensions of Narcissism $(n=73)$.

\begin{tabular}{ccc}
\hline Measurements & Frequency & Percentage \\
Authority & 198 & $19 \%$ \\
Exhibitionism & 180 & $17 \%$ \\
Entitlement & 135 & $13 \%$ \\
Exploitativeness & 182 & $18 \%$ \\
Superiority & 109 & $11 \%$ \\
Self-Sufficiency & 156 & $15 \%$ \\
Vanity & 69 & $7 \%$ \\
\hline
\end{tabular}


Table 5. Correlation coefficients among the 7 dimensions of Narcissism, the gender, and the similarity rating $(\mathrm{n}=73)$.

\begin{tabular}{|c|c|c|c|c|c|c|c|c|c|c|c|}
\hline Measurements & Authority & Exhibitionism & Superiority & Entitlement & Exploitativeness & Self-Sufficiency & Vanity & Gender & $\begin{array}{l}\text { Similarity } \\
\text { Ratings }\end{array}$ & Measurements & Authority \\
\hline Authority & - & & & & & & & & & & \\
\hline Exhibitionism & $0.59^{* *}$ & - & & & & & & & & & \\
\hline Superiority & $0.52^{* *}$ & $0.59^{* *}$ & - & & & & & & & & \\
\hline Entitlement & $0.59^{* *}$ & $0.58^{* *}$ & $0.53^{* *}$ & - & & & & & & & \\
\hline Exploitativeness & $0.32^{* *}$ & 0.19 & $0.25^{*}$ & $0.33^{* *}$ & - & & & & & & \\
\hline Self-Sufficiency & $0.53^{* *}$ & $0.43^{* *}$ & $0.48^{* *}$ & $0.48^{* *}$ & $0.29^{* *}$ & - & & & & & \\
\hline Vanity & $0.32^{* *}$ & $0.23^{*}$ & $0.30^{* *}$ & $0.24^{*}$ & 0.01 & 0.17 & - & & & & \\
\hline Aggression & $0.57^{* *}$ & $0.50^{* *}$ & $0.50^{* *}$ & $0.87^{* *}$ & $0.76^{* *}$ & $0.49^{* *}$ & 0.17 & - & & & \\
\hline Non-Aggression & $0.84^{* *}$ & $0.82^{* *}$ & $0.79^{* *}$ & $0.68^{* *}$ & $0.31^{* *}$ & $0.72^{* *}$ & $0.46^{* *}$ & $0.63^{* *}$ & - & & \\
\hline Gender & $-0.21^{*}$ & $-0.21^{*}$ & -0.08 & -0.13 & -0.11 & -0.10 & $-0.22^{*}$ & -0.15 & $-0.22^{*}$ & - & \\
\hline $\begin{array}{c}\text { Similarity } \\
\text { Rating }\end{array}$ & 0.06 & -0.00 & 0.11 & 0.09 & -0.06 & $0.20^{*}$ & 0.13 & 0.03 & 0.12 & 0.07 & - \\
\hline
\end{tabular}

Note: ${ }^{*} p<0.05 ;{ }^{* *} p<0.01$ (one-tailed).

\section{Discussion}

This study examined why paintings of the Venus plaster resemble the painters themselves. This study assumed that the similarity of the paintings with the painters would be associated with narcissistic personality traits. The results indicated that the degree of facial similarity in the paintings was correlated with narcissism of the painters. This study discusses the evidence for these conclusions separately in the following sections.

\subsection{Facial Similarity Judgments}

Based on the facial similarity rating data (see Table 3), the raters certainly perceived the phenomenon of the similarities between the painters' faces and their Venus paintings. However, more than half of the raters seemed to consider between the "alike" and "unalike" ratings. Moreover, some of the participants made judgments that were slightly similar to those of the raters. The most likely explanation for this observation is that the similarity might have been difficult to identify because human faces typically share similar or common features (e.g., eyes, a nose, a mouth, and ears) (Lin et al., 2011; Proverbio et al., 2007). However, people possess an extraordinarily well-developed ability to process, recognize and extract information from the faces of others (Little et al., 2011). Additionally, the facial similarity judgments produced by the participants in this study produced varied in terms of agreement with the facial similarity judgments that were predetermined by the investigators. Not everyone has the same preferences or finds the same elements to be pleasing. This study considers that future studies will more comprehensively characterize narcissistic designers via the inclusion of greater numbers of participants.

\subsection{Self-Image of the Narcissistic Personality}

According to the narcissism data presented in Table 4, the statistical results indicated that one narcissistic personality dimension might have caused the phenomenon of facial similarity (Penton-Voak et al., 1999). The painters who exhibited the self-sufficiency component, which has been argued to be an indicator of the positive personality trait of "non-aggression", might also exhibit an underlying tendency for producing self-similar images (Reidy et al., 2008). The results confirmed that the evidence that suggests that narcissistic personalities affect people’s behaviors and visual aesthetic attitudes (Frois \& Eysenck, 1995; Furnham \& Chamorro-Premuzic, 2004; Götz et al., 1979; Myszkowski et al., 2014).

It would be interesting to clarify why the painters who exhibited the self-sufficiency component in this study also exhibited the self-image phenomenon in their Venus paintings. The first possible reason might be that these narcissistic painters were more likely to be attracted by their own faces (Little et al., 2003, 2011; Bereczkei et al., 2002; Holtzman \& Strube, 2010; Moskowitz et al., 2009; Penton-Voak et al., 1999; Zajonc et al., 1987). This supposition would indicate that narcissistic people are more confident, feel better than others, and are more self- 
centered in their comparisons of the things around them. Such people can easily separate their emotions and transfer their emotions into paintings to express their emotions because it was indirectly correlated with the "counter-transference" management ability through the independent trait of responsibility. For example, the self-sufficiency of art therapists can remain independent of responsibility, and such therapists would be capable of discriminating their desires from those of the clients in their therapy (Jiyoung \& Gabsook, 2013) and capable of properly handling their counter transference feelings. Therefore, such narcissistic painters would automatically project their own senses of personal feelings into their drawing, which would naturally tend to resemble themselves.

Another possible explanation is that self-sufficient narcissists desire to be loved, which results in an unconscious expression of themselves in their paintings that is intended to draw attention to themselves. This unconscious dependency on external sources of love represents a significant source of vulnerability that must be defended against with narcissistic defenses that seek to create an illusion of self-sufficiency (Modell, 1975). This line of reasoning might explain why self-sufficient narcissists of involving expect to arouse the attention of other by expressing their best idealized characteristics (Campbell et al., 2000; Kurt \& Paulhus, 2008), such as assertiveness, independence, self-confidence, and the need for achievement (Raskin et al., 1988).

\section{Conclusion}

Although examinations of the relationships between personality and narcissismtraits and paintings are rather new in the design field, the present experiment successfully revealed the varied narcissistic dimension of the participants by presenting paintings with photos of their painters. This study considers that the present study offers new insights into the associations between paintings and narcissistic personalities, it also has some limitations. The first limitation is that this study used examined a number of assessments of facial similarity; consequently, the narcissism results of the current study cannot be generalized to these paintings. The second limitation is that the generalizability of the results to other populations with varying degrees of familiarity might be limited. The sensitivity of the similarity recognitions might have depended on the participants' familiarities because most of the participants in this study knew the creators of the paintings. This study speculates that strangers might have reported different views and that would have affected the results of the assessment. This study considers that this paper represents a reasonably good start of the development of a measure of narcissism. Future research into the development of such an inventory should include efforts to use the existing measure and its factor structure to develop a larger item that will more exhaustively sample the domains of narcissistic behaviors and learning achievement in design.

\section{References}

Ackerman, R. A., Witt, E. A., Donnellan, M. B., Trzesniewski, K. H., Robins, R. W., \& Kashy, D. A. (2011). What Does the Narcissistic Personality Inventory Really Measure? Assessment, 18, 67-87.

Anastasi, A., \& Urbina, S. (1994). Psychological Testing. New Jersey, USA: Prentice Hall Press.

Armstrong, R. G., \& Hauch, P. A. (1961). Sexual Identification and the First Figure Drawn. Journal of Consulting Psychology, 25, 51-54. http://dx.doi.org/10.1037/h0044138

Aronoff, D. N., \& McCormick, N. B. (1990). Sex, Sex Role Identification, and College Students' Projective Drawings. Journal of Clinical Psychology, 46, 460-466. http://dx.doi.org/10.1002/1097-4679(199007)46:4<460::AID-JCLP2270460414>3.0.CO;2-S

Arteche, A., Bandeira, D., \& Hutz, C. S. (2010). Draw-a-Person Test: The Sex of the First-Drawn Figure Revisited. The Arts in Psychotherapy, 37, 65-69. http://dx.doi.org/10.1016/j.aip.2009.09.002

Becker, B., Bell, M., \& Billington, R. (2006). Object Relations Ego Deficits in Bulimic College Women. Psychodynamics and Psychopathology, 43, 92-95.

Bereczkei, T., Gyuris, P., \& Bernath, K. L. (2002). Homogamy, Genetic Similarity, and Imprinting; Parental Influence on Mate Choice Preferences. Personality and Individual Differences, 33, 677-690. http://dx.doi.org/10.1016/S0191-8869(01)00182-9

Brudniy, A., \& Demilhanova, A. (2012). The Virtual Reality in a Context of the "Mirror Stage”. International Journal of Advances in Psychology, 1, 6-9.

Campbell, W. K., Reeder, G. D., Sedikides, C., \& Elliot, A. J. (2000). Narcissism and Comparative Self-Enhancement Strategies. Journal of Research in Personality, 34, 329-347. http://dx.doi.org/10.1006/jrpe.2000.2282 
Corry, N., Merritt, R. D., Mrug, S., \& Pamp, B. (2008). The Factor Structure of the Narcissistic Personality Inventory. Journal of Personality Assessment, 90, 593-600. http://dx.doi.org/10.1080/00223890802388590

Daoud, F. S., \& Breik, W. D. (2009). Relationship between Family Structure Variables and Sexual Identification as Measured by the Draw-A-Person Test. Social Behavior and Personality, 37, 545-553. http://dx.doi.org/10.2224/sbp.2009.37.4.545

Dimaggio, G., Lysaker, P. H., Carcione, A., Nicolò, G., \& Semerari, A. (2008). Know Yourself and You Shall Know the Other...to a Certain Extent: Multiple Paths of Influence of Self-Reflection on Mindreading. Consciousness and Cognition, 17, 778-789. http://dx.doi.org/10.1016/j.concog.2008.02.005

Emmons, R. A. (1984). Factor Analysis and Construct Validity of the Narcissistic Personality. Psychological Inquiry, 48, 291-300.

Frois, J. P., \& Eysenck, H. (1995). The Visual Aesthetic Sensitivity Test Applied to Portuguese Children and Fine Arts Students. Creativity Research Journal, 8, 277-284. http://dx.doi.org/10.1207/s15326934crj0803_6

Furnham, A., \& Chamorro-Premuzic, T. (2004). Personality, Intelligence, and Art. Personality and Individual Differences, 36, 705-715. http://dx.doi.org/10.1016/S0191-8869(03)00128-4

Goodenough, F. L., \& Harris, D. B. (1950). Studies in the Psychology of Children’s Drawings II: 1928-1949. Psychological Bulletin, 47, 369-433. http://dx.doi.org/10.1037/h0058368

Green, P. E., \& Smith, S. M. (1989). Multidimensional Scaling Concepts and Applications. Boston, MA: Allyn and Bacon Press.

Guez, J., Lev-Wiesel, R., Valetsky, S., Sztul, D. K., \& Pener, B. S. (2010). Self-Figure Drawings in Women with Anorexia; Bulimia; Overweight; and Normal Weight: A Possible Tool for Assessment. The Arts in Psychotherapy, 37, 400-406. http://dx.doi.org/10.1016/j.aip.2010.09.001

Götz, K. O., Borisy, A. R., Lynn, R., \& Eysenck, H. J. (1979). A New Visual Aesthetic Sensitivity Test: I. Construction and Psychometric Properties. Perceptual and Motor Skills, 49, 795-802. http://dx.doi.org/10.2466/pms.1979.49.3.795

Hammer, E. F. (1997). Advances in Projective Drawing Interpretation. Springfield, IL: Thomas Press.

Haworth, M. R., \& Normington, C. J. (1961). A Sexual Differentiation Scale for the D-A-P Test (for Use with Children). Journal of Projective Techniques, 25, 441-450. http://dx.doi.org/10.1080/08853126.1961.10381064

Holtzman, N. S., \& Strube, M. J. (2010). Narcissism and Attractiveness. Journal of Research in Personality, 44, $133-136$. http://dx.doi.org/10.1016/j.jrp.2009.10.004

Hsiao, S. W., \& Chen, C. H. (1997). A Semantic and Shape Grammar Based Approach for Product Design. Design Studies, 18, 275-296. http://dx.doi.org/10.1016/S0142-694X(97)00037-9

Isaksson, C., Norlen, A. K., Englund, B., \& Lindqvist, R. (2009). Changes in Self-Image as Seen in Tree Paintings. Arts in Psychotherapy, 36, 304-312. http://dx.doi.org/10.1016/j.aip.2009.07.004

Jiyoung, L., \& Gabsook, K. (2013). Effects of Narcissistic Personality Traits and Interpersonal Relationship Tendencies of Art Therapists on Their Countertransference Management Ability. The Arts in Psychotherapy, 40, 298-305. http://dx.doi.org/10.1016/j.aip.2013.05.008

Kohut, H. (1971). The Analysis of the Self. New York: International University Press.

Kohut, H. (1977). The Restoration of the Self. New York: International University Press.

Kubarych, T. S., Deary, I. J., \& Austin, E. J. (2004). The Narcissistic Personality Inventory: Factor Structure in a Non-Clinical Sample. Personality and Individual Differences, 36, 857-872. http://dx.doi.org/10.1016/S0191-8869(03)00158-2

Kurt, A., \& Paulhus, D. L. (2008). Moderators of the Adaptiveness of Self-Enhancement: Operationalization, Motivational Domain, Adjustment Facet, and Evaluator. Journal of Research in Personality, 42, 839-853.

http://dx.doi.org/10.1016/j.jrp.2007.11.005

Lin, M. H., Wang, C. Y., Cheng, S. K., \& Cheng, S. H. (2011). An Event-Related Potential Study of Semantic Style-Match Judgments of Artistic Furniture. International Journal of Psychophysiology, 82, 188-195. http://dx.doi.org/10.1016/j.ijpsycho.2011.08.007

Little, A. C., Jones, B. C., \& DeBruin, L. M. (2011). Facial Attractiveness: Evolutionary Based Research. Philosophical Transactions of the Royal Society, 366, 1638-1659. http://dx.doi.org/10.1098/rstb.2010.0404

Little, A. C., Penton-Voak, I. S., Burt, D. M., \& Perrett, D. I. (2003). Investigating an Imprinting-Like Phenomenon in Humans: Partners and Opposite-Sex Parents Have Similar Hair and Eye Colour. Evolution and Human Behavior, $24,43-51$. http://dx.doi.org/10.1016/S1090-5138(02)00119-8

Machover, K. (1949). Personality Projection in the Drawing of the Human Figure: A Method of Personality Investigation. Springfield, IL: Charles C Thomas Press. http://dx.doi.org/10.1037/11147-000

McHugh, A. (1966). Children's Figure Drawings in Neurotic and Conduct Disturbances. Journal of Clinical Psychology, 22, 
219-221. http://dx.doi.org/10.1002/1097-4679(196604)22:2<219::AID-JCLP2270220232>3.0.CO;2-P

Modell, A. H. (1975). A Narcissistic Defense against Affects and the Illusion of Self-Sufficiency. International Journal of Psychoanalysis, 56, 275-282.

Moskowitz, D. A., Rieger, G., \& Seal, D. W. (2009). Narcissism, Self-Evaluations, and Partner Preferences among Men Who Have Sex with Men. Personality and Individual Differences, 46, 725-728. http://dx.doi.org/10.1016/j.paid.2009.01.033

Myszkowski, B., Storme, M., Zenasni, F., \& Lubart, T. (2014). Is Visual Aesthetic Sensitivity Independent from Intelligence, Personality and Creativity? Personality and Individual Differences, 59, 16-20.

http://dx.doi.org/10.1016/j.paid.2013.10.021

Nagamachi, M. (1995). Kansei Engineering: A New Ergonomic Consumer Oriented Technology for Product Development. International Journal of Industrial Ergonomics, 15, 3-11. http://dx.doi.org/10.1016/0169-8141(94)00052-5

Penton-Voak, I. S., Perrett, D. I., \& Peirce, J. W. (1999). Computer Graphic Studies of the Role of Facial Similarity in Judgements of Attractiveness. Current Psychology: A Journal for Diverse Perspectives on Diverse Psychological Issues, 18, 104-117. http://dx.doi.org/10.1007/s12144-999-1020-4

Pincus, A. L., \& Lukowitsky, M. R. (2010). Pathological Narcissism and Narcissistic Personality Disorder. Annual Review of Clinical Psychology, 6, 421-446. http://dx.doi.org/10.1146/annurev.clinpsy.121208.131215

Proverbio, A. M., Zotto, M. D., \& Zani, A. (2007). The Emergence of Semantic Categorization in Early Visual Processing: ERP Indices of Animal vs. Artifact Recognition. BMC Neuroscience, 8, 24. http://dx.doi.org/10.1186/1471-2202-8-24

Raskin, R., \& Hall, C. S. (1979). A Narcissistic Personality Inventory. Psychological Reports, 45, 590. http://dx.doi.org/10.2466/pr0.1979.45.2.590

Raskin, R., \& Hall, C. S. (1981). The Narcissistic Personality Inventory: Alternative Form Reliability and Further Evidence of Construct Validity. Journal of Personality Assessment, 45, 159-162. http://dx.doi.org/10.1207/s15327752jpa4502 10

Raskin, R., \& Novacek, J. (1989). An MMPI Description of the Narcissistic Personality. Journal of Personality Assessment, 53, 66-80. http://dx.doi.org/10.1207/s15327752jpa5301 8

Raskin, R., \& Terry, H. (1988). A Principal-Components Analysis of the Narcissistic Personality Inventory and Further Evidence of Its Construct Validity. Journal of Personality and Social Psychology, 54, 890-902. http://dx.doi.org/10.1037/0022-3514.54.5.890

Reidy, D. E., Zeichner, A., Foster, J. D., \& Martinez, M. A. (2008). Effects of Narcissistic Entitlement and Exploitativeness on Human Physical Aggression. Personality and Individual Differences, 44, 865-875. http://dx.doi.org/10.1016/j.paid.2007.10.015

Rushton, J. P., \& Bons, T. A. (2005). Mate Choice and Friendship in Twins: Evidence for Genetic Similarity. Psychological Science, 16, 555-559. http://dx.doi.org/10.1111/j.0956-7976.2005.01574.x

Sidun, N. M., \& Rosenthal, R. H. (1987). Graphic Indicators of Sexual Abuse in "Draw-A-Person” Tests of Psychiatrically Hospitalized Adolescents. Arts in Psychotherapy, 14, 25-33. http://dx.doi.org/10.1016/0197-4556(87)90032-3

Skybo, T., Ryan-Wenger, N., \& Su, Y. (2007). Human Figure Drawings as a Measure of Children's Emotional Status: Critical Review for Practice. Journal of Pediatric Nursing, 22, 15-28. http://dx.doi.org/10.1016/j.pedn.2006.05.006

Stucke, T. S., \& Sporer, S. L. (2002). When a Grandiose Self-Image Is Threatened: Narcissism and Self-Concept Clarity as Predictors of Negative Emotions and Aggression Following Ego-Threat. Journal of Personality, 70, 509-532. http://dx.doi.org/10.1111/1467-6494.05015

Swensen, C. H. (1968). Empirical Evaluations of Human Figure Drawings: 1957-1966. Psychological Bulletin, 70, 20-44. http://dx.doi.org/10.1037/h0026011

Vass, Z. (2012). A Psychological Interpretation of Drawings and Paintings. The SSCA Method: A Systems Analysis Approach. Budapest: Alexandra Press.

Vazire, S., Naumann, L. P., Rentfrow, P. J., \& Gosling, S. D. (2008). Portrait of a Narcissist: Manifestations of Narcissism in Physical Appearance. Journal of Research in Personality, 42, 1439-1447. http://dx.doi.org/10.1016/j.jrp.2008.06.007

Willcock, E., Imuta, K., \& Hayne, H. (2011). Children’s Human Figure Drawings Do Not Measure Intellectual Ability. Journal of Experimental Child Psychology, 110, 444-452. http://dx.doi.org/10.1016/j.jecp.2011.04.013

Zajonc, R. B., Adelmann, P. K., Murphy, S. T., \& Niedenthal, P. M. (1987). Convergence in the Physical Appearance of Spouses. Motivation and Emotion, 11, 335-346. http://dx.doi.org/10.1007/BF00992848 